\title{
韓国におけるパルプ供給の見通し*
}

\section{An Outlook for Fiber Supply in Korea}

\author{
Byung-Ho Yoon and In-Hwa Choi \\ Department of Paper Science and Engineering \\ Kangwon National University, Korea
}

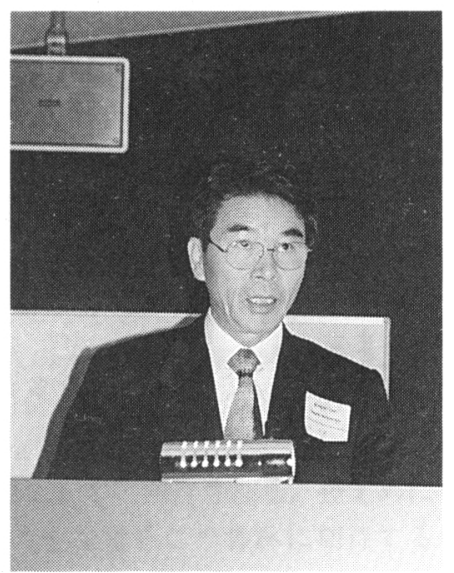

Byung-Ho Yoon

Paper is used as a cultural transmitter and a life essential in our daily life. In particular, paper is light and easy for cutting, folding, tearing, etc. While it is easy deteriorated by insects or microbes. As a friendly substance to environment, therefore, it will go together with the human being forever. As of 1996, the production volume of both paper and paperboard in Korea totaled 7,681,000 metric tons and the paper consumption a citizen averaged $150.2 \mathrm{~kg}$. The principal meterial of paper having such importance is wood, specifically pulp. The production amount of pulp in Korea was 531,759 tons, accounting to $25 \%$ of her total demand for the year, which was covered by Hansol Paper (GP 51,196 tons; TMP 13,247tons), Sejong Paper (GP 23,782 tons), Daehan Paper (GP 9,299 tons), and Donghae Pulp for the remainder (BKP 319,232 tons). The production of pulp in Korea needs wood and chips domestically as well as abroad. Korea is very short of wood, not to speak of pulp.

Considering the situation facing Korea, therefore, this review intends to discuss in more detail the situation and forecast of the production of pulping wood in Korea and the status of demand for and supply of virgin pulp and waste paper.

(quoted from the original paper)

\section{1.はじめに}

紙は現在，文化の媒体あるいは生活必需品として日 常的に使われている。軽く，切りやすく，盢みやすく， 破りやすいという特徵があるが, 一方で虫や微生物の 害にもあいやすい。したがって，環境に優しい物質と してこれからも長く人類に必要とされるであろう。 韓国における紙・板紙の生産は, 1996 年について

\footnotetext{
*(翻訳) 株式会社日本紙パルプ研究所 青柳 哲夫
}

いえば合計で 768 万 1,000 トンで，国民 1 人当たりの 紙消費量は $150.2 \mathrm{~kg}$ であった（表 1)。紙の原材料で 最も重要なのは言うまでもなくパルプであるが，韓国 に扮けるパルプ生産高は 53 万 1,759 トンで，これは 韓国国内の需要の $25 \%$ に当たる。パルプを生産して いるのは，ハンソル製紙（内訳はGP 5 万 1,196トン， TMP 1 万 3,247トン)，セジョン製紙（GP 2 万 3,782トン)，デハン製紙 (GP 9,299 トン)，ドンへ パルプ社（BKP 31 万 9,232トン）である。韓国国内 でのパルプ生産に 1995 年に使われた原料は, 原木お 
Table 1 Introduction of Korean wood and pulp resources

Forest Area : 6, 451, 885 ha

Forest Growing stock : 308,825,576 $\mathrm{m}^{3}$

Paper Production : 7,681,000 M/T

Paper Consumption : 6,121,000 M/T

A Citizen : $150.2 \mathrm{~kg}$

Total Demand for Pulp Production : 2,526,000 MT

Pulp Production in Korea : 560,328 tons

Demand for Pulping Wood : 1,390,000 $\mathrm{m}^{3}$

Supply of in-country Pulping Wood : 419,000 $\mathrm{m}^{3}$

よびチップを併せて 1,567 万 $8,000 \mathrm{~m}^{3}$ (原文通り。 韓国国内のパルプ生産量 53 万トンに対するパルプ材 としてはあまりにも大きい。数字の由来は不明（訳 者)）であった。そのうち 41 万 $9,000 \mathrm{~m}^{3}$ は国内産 (これは後述の国内産パルプ材と一致する。(訳者))で, 残りの 1,525 万 $2,000 \mathrm{~m}^{3}$ は輸入である。

韓国は, 国内で供給できるパルプと木材資源が不足 しており，輸入に大きく依存している。このレビュー では韓国のパルプ材の生産状況と見通し，およびバー ジンパルプおよび古紙の需給状況について述べる。

\section{2. パルプ材およびパルプ需給の現状}

\section{1 木材の供給}

韓国における木材消費は経済成長，あるいは国民の 生活水準の改善と共に増加してきた。たとえば丸太の 供給は, 1970 年の 400 万 $\mathrm{m}^{3}$ から, 1995 年末には 928 万 $4,000 \mathrm{~m}^{3}$ にまで増加している。この 25 年間に 2.3 倍になった。年率にすると $3.4 \%$ である。1970 年およ
び 1995 年の国内産丸太の供給は，それぞれ 84 万 $5,000 \mathrm{~m}^{3}$ および 98 万 $5,000 \mathrm{~m}^{3}$ で，この 25 年間の供 給増加はほとんど輸入丸太の増加に依存している。丸 太の場合，自給率はこの間に，1970 年の $21 \%$ から， 1995 年には $11 \%$ にで低下している。表 2 の最近数 年間の全木材供給の数字からも明らかなように，国内 産木材はほとんど増減なく一定しており, 外国からの 輸入の増加がほぼ全木材供給の増加に相当する。

1995 年の木材の全供給量は 3,367 万 $7,000 \mathrm{~m}^{3}$ であ つた。内訳は輸入が 3,224 万 $2,000 \mathrm{~m}^{3}(96 \%)$ を占め, 国内産材は 143 万 $5,000 \mathrm{~m}^{3}$ で，韓国の木材自給率は たったの $4 \%$ である。

\section{2 パルプ材の供給}

パルプ材の全供給量は 1988 年の $687,000 \mathrm{~m}^{3}$ から 1995 年には 124 万 $3,000 \mathrm{~m}^{3}$ に増加した（表 3)。全供 給量が 1.8 倍になったことでパルプ材の国内自給率は $98 \%$ から $34 \%$ へと急落した。1995 年の供給を用途別 にみると, 27 万 $5,000 \mathrm{~m}^{3}$ が機械パルプ向けで 96 万

Table 2 The status of supply of wood

\begin{tabular}{|c|c|c|c|c|c|c|}
\hline \multirow{3}{*}{ Year } & \multicolumn{6}{|c|}{ Wood supplied $\left(1,000 \mathrm{~m}^{3}\right)$} \\
\hline & \multirow[b]{2}{*}{ Total } & \multirow{2}{*}{$\begin{array}{c}\text { Domestic } \\
\text { wood }^{1)}\end{array}$} & \multicolumn{3}{|c|}{ Imported wood } & \multirow{2}{*}{$\begin{array}{c}\text { Self- } \\
\text { sufficienc } \\
y\end{array}$} \\
\hline & & & Subtotal & $\log ^{1)}$ & $\begin{array}{c}\text { Wood } \\
\text { products }^{2)}\end{array}$ & \\
\hline 1992 & $26,898(100)$ & $1,338(5)$ & 25,560 & $8,728 \quad(32)$ & $16,832(63)$ & 5 \\
\hline 1993 & $30,166(100)$ & $1,379(5)$ & $28,787 \quad(95)$ & $7,725(25)$ & $21,062(70)$ & 5 \\
\hline 1994 & $31,310(100)$ & $1,331(4)$ & $29,979(96)$ & $7,711 \quad(25)$ & $22,268(71)$ & 4 \\
\hline 1995 & $33,677(100)$ & $1,435(4)$ & $32,242(96)$ & $8,398 \quad(25)$ & $23,844 \quad(71)$ & 4 \\
\hline
\end{tabular}

(Source : the Research Institute of Forestry)

${ }^{1)}$ The data for in-country wood and material wood may have slight difference from the statistical data by the Office of Forestry.

${ }^{2)}$ The figures for the wood products represent figures for the amount of the meterial wood produced through conversion. 
Table 3 The status of supply of pulping wood by year

(Unit : $1,000 \mathrm{~m}^{3}$ )

\begin{tabular}{c|c|c|c|c|c|c|c|c|c}
\hline \multirow{2}{*}{ Year } & \multicolumn{2}{|c|}{ Total } & \multicolumn{3}{c|}{ Mechanical pulp wood } & \multicolumn{4}{c}{ Chemical pulp wood } \\
\cline { 2 - 9 } & Supply & $\begin{array}{c}\text { Self-sufficiency } \\
(\%)\end{array}$ & Subtotal & Softwood & Import & Total & Hardwood & Softwood & Import \\
\hline 1988 & 687 & 98 & 252 & 252 & - & 435 & 236 & 143 & 56 \\
1989 & 664 & 80 & 230 & 230 & - & 433 & 187 & 113 & 133 \\
1990 & 641 & 80 & 203 & 203 & - & 438 & 204 & 105 & 129 \\
1991 & 682 & 68 & 256 & 201 & 55 & 426 & 192 & 70 & 164 \\
1992 & 681 & 65 & 257 & 245 & 12 & 424 & 141 & 59 & 224 \\
1993 & 1,066 & 38 & 245 & 245 & - & 821 & 132 & 25 & 664 \\
1994 & 1,220 & 36 & 284 & 284 & - & 936 & 149 & - & 787 \\
1995 & 1,243 & 34 & 275 & 268 & 7 & 968 & 151 & - & 817 \\
\hline
\end{tabular}

(Source: The Trend of Forest Economy, the Research Institute of Forestry, 1996)

8,000 $\mathrm{m}^{3}$ が化学パルプ向けであった。機械パルプの 大半は韓国国内産の適木を原料に製造されたが， 96 万 $8,000 \mathrm{~m}^{3}$ 使われた化学パルプ向け原料のうち, 韓 国国内産の原料（広葉樹材）は 15 万 $1,000 \mathrm{~m}^{3}$ （16\%） に過ぎず，輸入原料の占める割合が高い。

購入パルプ原料のトレンドは以下の通りである。機 械パルプ用原料は 1991 年にはチップでの購入が 0.5\%であったのが, 1995 年には $26 \%$ になった。した がって，購入する原料の形態は丸太からチップへと 徐々に変わってきている。化学パルプの原料について は 1993 年以来すべてチップで購入している（表 4)。

一方, パルプ材不足が解消する目途が立たないため, 韓国の製紙産業には海外植林を進める機運が高まって いる。海外植林は韓国企業と海外の地元企業の合弁事 業として実施される場合が多いが, 現在進んでいる海 外植林の面積規模は数十万 ha を越えない。長期にわ たって安定的にパルプ原料の供給を可能とするために は海外植林の規模を拡大することが急務である。

\section{3. パルプの供給}

韓国の紙生産高は 1965 年には 12 万トンであったが, 1970 年には 32 万 9,000 トン, 1980 年には 160 万トン
と増えてきている。1981 年から 1987 年にかけては, 国の言論統廃合政策により新聞用紙, 印刷用紙の生産 が減り続けた。しかし，1987 年以降は紙の需要が再 び増加傾向を取り戻した。1996 年には 109 の製紙会 社が紙 768 万 1,158 トンを生産した。この 30 年間で 生産高が 60 倍になったことになる。

このような紙の生産に必要な原料パルプも增加した。 バージンパルプと古紙でみると 1970 年にはそれぞれ 23 万 9,000 トン（これには 15 万 9,000 トンの輸入パ ルプを含む）および 12 万 9,000 トンであったものが, 1985 年には 83 万 5,000 トン（輸入パルプ 56 万 7,000 トンを含む）および 151 万 8,000 トンへと增加した。 1996 年にはこの両者はそれぞれ 252 万 6,000 トン (輸入パルプ 196 万 6,000トンを含む) および 539 万 1,000 トン（144万 8,000 トンの輸入古紙を含む）に 達した（表 5)。1960 年から 1970 年までの時期の韓国 では，新聞用紙に使われていた GP と UKP，および 僅かな量のワラパルプしか製造されていなかった。 1980 年代になって BKP 工場の稼㗢に伴ってパルプ の日産量が 300-400トンになった。その後さらに生産 量が增え続けて 1993 年には日産量が 1,100 トンに,

Table 4 Pulpwood used in Pulp Production

\begin{tabular}{c|r|r|r|r|r|r|r|r}
\hline & 1980 & 1985 & 1990 & 1992 & 1993 & 1994 & 1995 & 1996 \\
\hline Log & 427 & 214 & 250 & 256 & 243 & 306 & 324 & 355 \\
Chip & 45 & 355 & 494 & 554 & 838 & 879 & 1,088 & 1,035 \\
Total & 472 & 569 & 744 & 810 & 1,081 & 1,185 & 1,412 & 1,390 \\
\hline
\end{tabular}

(Source: Korea Paper Manufacturers' Association, 1996) 
Table 5 Pulp Demand and Supply Trend

(Unit : M/T)

\begin{tabular}{|c|c|c|c|c|c|c|c|c|c|}
\hline & \multicolumn{3}{|c|}{ Total } & \multicolumn{3}{|c|}{ Production } & \multicolumn{3}{|c|}{ Imports } \\
\hline & Total & $\begin{array}{c}\text { Ground- } \\
\text { wood } \\
\text { pulp }\end{array}$ & $\begin{array}{c}\text { Chemical } \\
\text { Pulp }\end{array}$ & Total & $\begin{array}{c}\text { Ground- } \\
\text { wood } \\
\text { Pulp }\end{array}$ & $\begin{array}{c}\text { Chemical } \\
\text { pulp }\end{array}$ & Total & $\begin{array}{c}\text { Ground- } \\
\text { wood } \\
\text { Pulp }\end{array}$ & $\begin{array}{c}\text { Chemical } \\
\text { pulp }\end{array}$ \\
\hline 1975 & $325,250 \quad(29)$ & 102,026 & & 93,802 & 87,109 & 6,693 & & 14,917 & \\
\hline 1980 & $608,503(27)$ & 155,843 & 452,660 & 167,097 & 137,441 & 29,656 & 441,406 & 18,402 & 423,004 \\
\hline 1985 & $834,611 \quad(32)$ & 163,926 & 670,685 & 267,661 & 138,444 & 129,217 & 566,950 & 25,482 & 541,468 \\
\hline 1990 & $1,457,612(21)$ & 169,766 & $1,287,846$ & 301,311 & 159,389 & 141,922 & $1,156,301$ & 10,377 & $1,145,924$ \\
\hline 1995 & $2,218,158$ & 249,226 & $1,968,932$ & 500,597 & 181,212 & 319,385 & $1,717,561$ & 68,104 & $1,649,547$ \\
\hline 1996 & $2,526,447 \quad(22)$ & 310,039 & $2,216,408$ & 560,328 & 222,524 & 337,804 & $1,966,119$ & 87,515 & $1,878,604$ \\
\hline
\end{tabular}

Note: Excluding the pulp for industrial use.

( ) : Self-sufficiency \%

年産が 35 万トンになった。1996 年現在のパルプ生産 高は GP，TMP を含めて 56 万トンである。

パルプ生産高の 53 万 1,000 トンは, パルプ需要の 217 万 3,000 トンの $25 \%$ を賄うに過ざないが, 国内の 生産能力に余裕がないため, どうしても需要の $75 \%$ に相当する 164 万 2,000 トンを輸入に頼らざるを得な い。輸入への依存度が大きいため, 安定かつ合理的な 価格でのパルプの輸入が不可欠になる。現在では, パ ルプは主として米国，カナダ，チリー，ブラジル，イ ンドネシアを含む 23 カ国から輸入している。輸入元 をこのように多元化しているので, 安定供給が困難な 場合もある。また, 韓国国内におけるパルプ生産設備 の拡張も考虑しなければならない。

1996 年のパルプ種別の輸入量（および種類別輸入 割合) は BKP 141 万 6,413 トン (71\%), UKP 27 万 1,449 トン (15\%), その他 10 万 2,264 トン (6\%), SKP 3 万 5,265 トン $(2 \%)$, BSP 2 万 7,274 レン (2\%) で他に GP，DP，USPが続く。これらの合計 額およびトン当たりの平均額はそれぞれ 8 億 2,751 万 5,182 米ドルおよび 445 米ドルである。

186 万 0,120 トンの輸入パルプの輸入元は, 米国 74 万 4,359トン, カナダ 57 万 8,830 トン, ブラジル 17 万 0,918 トン, ロシア 6 万 9, 568 トン, ニュージーラ ンド 6 万 0,105 トンなどが主な輸入元である（チリー からの輸入量は不詳。(訳者))。国別の輸入量は輸出 国の森林蓄積を反映している。

\section{3. パルプ材およびパルプ需給の展望}

\section{1 パルプ材}

林業局が 1993 年にまとめた木材供給の長期子測に
よれば，韓国の総木材需給量は 1992 年の 2,227 万 $5,000 \mathrm{~m}^{3}$ から 2040 年には 1.7 倍の 3,880 万 $\mathrm{m}^{3}$ への 増加を見込んでいる（表 6)。そのうち，国内産材は 1992 年の 112 万 $3,000 \mathrm{~m}^{3}$ から 2040 年には 1,379 万 $9,000 \mathrm{~m}^{3}$ へと 12.3 倍に著増している。結果として林 業局は総木材および工業原料木材の自給率としてそれ ぞれ 5\%から $36 \%$ および $12 \%$ から 59\%への増加を予 測している。

\section{2 パ ルプ}

1996 年現在の韓国の年間パルプ生産能力は, 唒化 学パルプ 40 万トン, 新聞紙向けの GP38 万 2,000 ト ンである。1996 年の総パルプ需要は 252 万 6,000 卜 ンであったが, そのうち 31 万トンを占める GP は 22 万トンが国内生産で賄われ，自給率は $71.8 \%$ であった。 化学パルプの場合は総需要量 221 万 6,000 トンのうち 韓国で生産された部分は 33 万トンで自給率は $15.2 \%$ に過ぎない（表 5)。一方輸入を輸入元でみると，力 ナダ，米国，チリー，ブラジル，インドネシアの 5 カ 国に総輸入量の $88 \%$ を頼り，残りは 23 力国からの分 である。

GP に関しては, 当分の間供給能力が需要量を上回 るので問題はなさそうである。化学パルプの場合，ド ンヘパルプ社の生産設備改善により日産能力は 1,150 トンにまで増加したが, 1990 年-2000 年期の需要增が 平均で年率 $8.3 \%$ であることを考虑すると, 自給率が 次第に低下することは避けられない（表 7)。したが って，現有の国内の製造設備の拡張だけでなく，森林 資源に恵まれている国々への投資あるいは合弁による 安定供給確保への努力が求められる。

実際に, 現在 2 つの韓国企業が海外の現地資本との 
Table 6 The long-term forecast of demand for and supply of wood

(Unit : $1,000 \mathrm{~m}^{3}$ )

\begin{tabular}{|c|c|c|c|c|c|c|c|}
\hline \multicolumn{2}{|c|}{ Year } & 1992 & 2000 & 2010 & 2020 & 2030 & 2040 \\
\hline \multicolumn{2}{|c|}{$\begin{array}{l}\text { Total demand for wood } \\
\qquad\left(1,000 \mathrm{~m}^{3}\right)\end{array}$} & 22,275 & 26,421 & 30,735 & 34,563 & 37,394 & 38,799 \\
\hline Supply & In-country & 1,123 & 2,542 & 4,787 & 7,530 & 10,852 & 13,799 \\
\hline$\left(1,000 \mathrm{~m}^{3}\right)$ & Import & 21,252 & 23,879 & 25,948 & 27,033 & 26,542 & 25,000 \\
\hline \multicolumn{2}{|c|}{$\%$ of Self-sufficiency } & 5 & 10 & 16 & 22 & 29 & 36 \\
\hline
\end{tabular}

(Source: The 5-Year Forestry Development Plan-New Economy, The Office of Forestry, 1993)

Table 7 Pulp Demand Prospects

\begin{tabular}{c|c|c|r|c|c|c}
\hline Year & Total & G.P & S.K.P & B.K.P & U.K.P & Others \\
\hline 1997 & 2,668 & 328 & 23 & 1,966 & 253 & 98 \\
1998 & 2,899 & 357 & 25 & 2,135 & 275 & 107 \\
1999 & 3,128 & 385 & 27 & 2,304 & 296 & 116 \\
2000 & 3,363 & 414 & 29 & 2,477 & 319 & 124 \\
\hline
\end{tabular}

合弁事業を進行あるいは計画している。これらの事業 で賄われる量は 45 万トンと見込まれている。

\section{3 古 紙}

パルプの自給率が $25 \%$ 以下であること，原料の長 期安定供給の観点から, 古紙の確保が差し迫った問題 として浮かび上がったことはすでに述べた。古紙の利 用は原料の自給率向上の方策として有効である。これ を推進することにより，森林資源が少ないことを補え， 環境問題解決の一助とでき, また原料コストを抑える ことができる。したがって韓国でも諸外国でも古紙利 用，特にその物理的性質が古紙を配合することで始め て満たされる新聞用紙の製造に関連して，その重要性 に対する関心が高まってきている。さらに白板紙や段 ボールなどの需要の増大に伴って古紙の有用性も增す
であろう。

1996 年についていえば，古紙の消費量は全体で 539 万1,000トンで，自給率は $70 \%$ にまで増加した。一 方で古紙全体の要求品質を維持するために, 高品質古 紙は継続して輸入されている。韓国が輸入した古紙 120 万 3,000トンの輸入元は米国 $(40 \%)$, カナダ (31.3\%), ブラジル $(9.2 \%)$, チリー $(6.9 \%)$, ニュ ージーランド $(3.2 \%)$ および他の 20 カ国にわたる。 表 8 には, 1985 年と 1996 年の国内発生分および輸入 古紙について，その内訳を新聞古紙，段ボール古紙お よび「その他」に分けて示した。「その他」には, 雑 誌古紙，オフィス古紙などが含まれる。

古紙の輸入量は 1980 年代後半から増え続けており, 特に段ボール古紙の消費はパッケージング産業の進展

Table 8 Trend of wastepaper demand and supply

(Unit : $1,000 \mathrm{M} / \mathrm{T}, \%$ )

\begin{tabular}{c|c|c|c|c|c|c|c|c|c|c|c|c}
\hline \multirow{2}{*}{$\begin{array}{l}\text { Supply } \\
\text { source }\end{array}$} & \multicolumn{3}{|c|}{ Total } & \multicolumn{3}{c|}{ O.N.P } & \multicolumn{3}{c|}{ O.C.C } & \multicolumn{3}{c}{ Others } \\
\cline { 2 - 13 } & Total & DWP & IWP & Total & DWP & IWP & Total & DWP & IWP & Total & DWP & IWP \\
\hline \multirow{2}{*}{1985} & 1,518 & 817 & 701 & 354 & 59 & 295 & 576 & 314 & 262 & 589 & 444 & 144 \\
& $(100)$ & $(53.8)$ & $(46.2)$ & $(100)$ & $(16.7)$ & $(83.3)$ & $(100)$ & $(54.5)$ & $(45.5)$ & $(100)$ & $(75.5)$ & $(24.5)$ \\
\hline \multirow{2}{*}{1996} & 5,391 & 3,943 & 1,448 & 1,424 & 851 & 573 & 2,295 & 1,927 & 367 & 1,672 & 1,165 & 507 \\
& $(100)$ & $(73.1)$ & $(26.9)$ & $(100)$ & $(59.8)$ & $(40.2)$ & $(100)$ & $(84.0)$ & $(16.0)$ & $(100)$ & $(69.7)$ & $(30.3)$ \\
\hline
\end{tabular}

Domestic wastepaper : DWP

Imported wastepaper : IWP 
に伴って 1990 年代の初めから飛躍的に增加した。そ の内容はバージンパルプで作られた北米からの段ボー ルが㤈である。

\section{4.むすび}

林業省は韓国の木材および木材製品自給率を現在の 4\%（丸太 $11 \%$ ）から 2040 年には 36\%（丸太 $59 \%$ ）

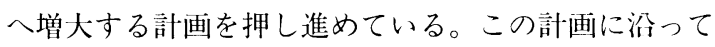
見通しを行うと，韓国は2040 年代も丸太については 需要の $40 \%$ ，またパルプ，チップ，合板を含めた 全木材製品についてはその需要の実に $70 \%$ を輸入に 頼らざるを得ない。将来のことを考えれば，現在の乏 しい森林資源を飛躍的に拡大寸ることによって，木材 の国内での持続的生産を具体化するべくさらに努力を 重ねなければならない。また同時に木材やパルプの需 給にたいする万全の準備も必要であろう。

製紙産業にとっては, 供給国の事情によってパルプ や古紙の供給, 特に価格上昇や供給量の変化といった, 紙を生産する上での困難が益々増大寸ると考えられる。 このような問題に対処するため, 輸入元の多元化, 海
外造林の拡大推進，木材生産国におけるパルプ生産の 推進などによって，木材およびパルプの安定供給のた めに必要な資源の確保に向けてより積極的に努力する ことが急務である。

さらに古紙についても，収益に考虑しながらリサイ クルの推進や回収率の増大を図るため, 関連施設の搪 充に努める必要がある。

\section{参考文献}

1) The Office of Forestry: The 5-Year Plan for Forestal Development-New Economy, pp.242 (1993)

2) The Office of Forestry: Annual Statistical Report on the Forestry, pp.562 (1996)

3) Woo Jong Choon: "Strategies for Securing Wood Resources", a Collection of Theses (No.14), presented to the Hansol Environment Seminar, pp.71-79 (1996)

4) Korea Paper Manufacturer's Association : Pulp and Waste Paper Statistics Yearbook (1997) 